\title{
Petrography and Provenance of Early Triassic Pachmarhi Formation Sandstones, Satpura Gondwana Basin, Madhya Pradesh, Central India
}

\author{
Abdullah Khan, Anis, Shahnawaz \\ Department of Geology, Aligarh Muslim University, Aligarh, India \\ Email: anis.ali17@gmail.com
}

Received December 3, 2012; revised January 3, 2013; accepted February 1, 2013

Copyright (C) 2013 Abdullah Khan et al. This is an open access article distributed under the Creative Commons Attribution License, which permits unrestricted use, distribution, and reproduction in any medium, provided the original work is properly cited.

\begin{abstract}
The Pachmarhi, Denwa and Bagra Formations comprise of terrigenous sediments predominantly constitute the Mesozoic Gondwana sequence in Satpura basin of Madhya Pradesh, central India. The Pachmarhi Formation sandstones were studied with a view to understand the nature of the Satpura basin in relation to provenance and tectonic setting. Twenty representative samples of sandstone from Pachmarhi were examined for detrital mineralogy, petrofacies and tectonic implications. These sandstones are medium to coarse grained, moderately to moderately well sorted, subangular to subrounded and of moderate sphericity and composed of several varieties of quartz, feldspar, rock fragments, mica and a suite of heavy minerals. Petrographically, the Pachmarhi sandstones are quartzarenite and subarkose. The petrofacies studies reflect derivation of the sediments from continental block provenance and stable cratonic to fault-bounded basement uplift tectonic setting. The study suggests that the Precambrian granitoids occurring in the southern margin of the Satpura basin contributed sediments during Pachmarhi sedimentation.
\end{abstract}

Keywords: Petrography; Provenance; Pachmarhi Formation; Satpura Basin; Madhya Pradesh

\section{Introduction}

The Gondwana strata of peninsular India record resumption of sedimentation during the Permo-Carboniferous period after a lond depositonal hiatus that began in the proterozoic. In peninsular India Gondwana successions are preserved in a number of discrete, intracratonic basins that record a depositional history up to the Cretaceous (Figure 1). These successions share the faunal and floral characteristics of the Gondwana strata of South America, South Africa, Australia and Antarctica and also resemble one another lithologically which comprises the other constituents of the southern hemispheric part (Gondwanaland) of the Paleozoic supercontinent Pangea. The successions start with basal diamictite and glacial outwash deposits, passing up to coal-bearing siliciclastic deposits with Glossopteris flora overlain by Triassic red beds with calcretes [1]. This paper presents a detailed account of Pachmarhi Formation exposed in east-central part of Satpura Gondwana basin. The Triassic succession in the east-central part of the Satpura basin comprises the Pachmarhi and the overlying Denwa Formations. The Pachmarhi Formation attains an average thickness of about
$750 \mathrm{~m}$ with a maximum of about $900 \mathrm{~m}$. It is dominantly arenaceous, comprising pebbly, gritty to very coarse and coarse to medium grained occurring as channel shaped multistorey bodies of 5 - $20 \mathrm{~m}$ thick. The sandstone are profusely cross-bedded with interbeds of horizontal bedded sandstone. The channel bodies are commonly characterized by 1 - $2 \mathrm{~m}$ thick interbeds of conglomerate or massive pebbly sandstone with an uneven erosional base. Pebbles are present almost throughout the sedimentary unit.

\section{Geological Setting}

The Gondwana basins of Peninsular India are intracratonic in nature surrounded by Precambrian terrains. They are disposed along ENE-WSW trending Narmada-SonDamodar valley, NNW-SSE trending Pranhita Godavari valley, NW-SE trending Mahanadi valley and E-W trending Satpura basin (Figure 1). There is general consensus that these basins originated under a bulk extensional regime due to failure of attenuated crust along preexisting zones of weakness imparted by Precambrian structural grains [2-6]. The Satpura basin of central India 


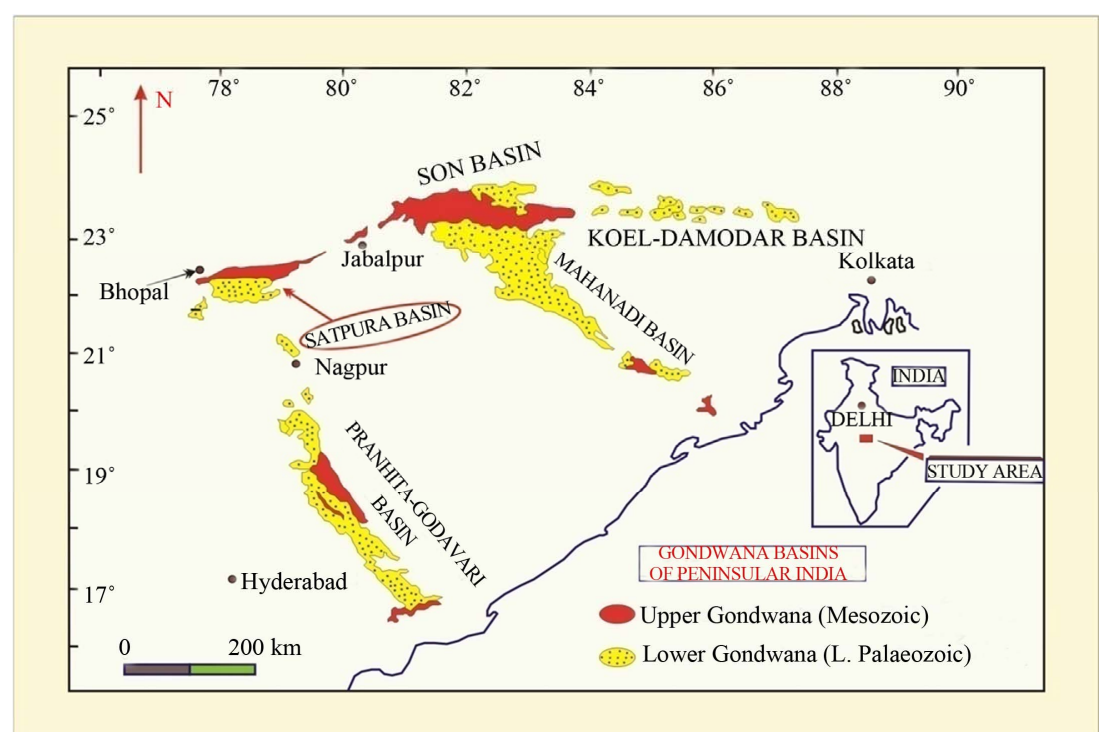

Figure 1. Map showing outcrops of the Gondwana basins in the peninsular India.

is the western most Indian Gondwana basin and outcrops along ENE-WSW trending Narmada-Son Damodar Valley (Figure 1). The basin is rhomb shaped, approximately $200 \mathrm{~km}$ long and $60 \mathrm{~km}$ wide. The Satpura basin was created as pull-apart basin due to extension related to strike-slip movement along the Son-Narmada Lineament $[7,8]$. The bulk of Satpura succession was deposited in a mega half graben bounded by basin margin fault controlled subsidence regimes with intervening tectonically static periods. Also, the subsidence rate varied across the basin resulting in an asymmetric basin fill with the thickness increasing towards the north [4]. The Satpura basin contains rocks of Permian to Cretaceous age and therefore comprises the longest stratigaraphic range of Indian Gondwana basins. Interistingly, the term Gondwana was introduced by Meddlicott [9] while he was working in the Satpura basin, after the ancient kingdom of Dravidian Gonds, one of the principal aboriginal tribes who still inhabited the Satpura area. The Gondwana sequence, known as Upper Gondwana, occurs in the central and northern parts of the Satpura basin. These comprise the Pachmarhi, Denwa and Bagra Formations (Table 1). The Pachmarhi Formation comprises recurring sequence of multistorey sandstones bodies which crop out largely in the southern and central parts as lofty hills and plateau (Figure 2). The Satpura Gondwana basin hosts a $\sim 5 \mathrm{~km}$ thick siliciclastic succession Permian-Cretaceous, [10] that unconformably lies over the Precambrian basement. The regional strike of the basin-fill strata is NE-SW, and the regional dip $\left(\sim 5^{\circ}\right)$ directed towords north. The PermoCretaceous Satpura Gondwana succession has been classified into seven major lithostratigraphic unit that form oldest to youngest are the Talchir, Baraker, Motur, Bijori, Pachmarhi, Denwa and Bagra formations (Figures 2 and 3, Table 1). Barring the lowermost glacio-marine and glacio-fluvial deposits, the rest of the succession largely comprises a variety of fluvial deposits with some records of fluvio-deltaic and fluvio-lacustrine sediments [11-16]. In the Satpura Gondwana basin, periods of maximum subsidence are indicated by glaciomarine, fluvio-deltaic and fluvio-lacustrine regimes that prevailed during the Talchir, Barakar and Bijori sedimentation respectively. Following the Bijori sedimentation, accumulation in the Satpura Gondwana basin took place under the alluvial regime indicating a decrease in the rate of subsidence [8].

The available paleogeographic reconstructions suggest that the Satpura basin had migrated from a position of $60^{\circ} \mathrm{S}$ latitude in Lower Permian to $30^{\circ} \mathrm{S}-40^{\circ} \mathrm{S}$ latitude by Middle Triassic [13,17-19] and thus had traversed through different climatic zones during this period. Sediment dispersal patterns indicate that the Precambrian terrain straddling the southern margin of the Satpura Gondwana basin was the most probable source for the Satpura Gondwana sediments [8]. In the study area, tonalite gneiss is a predominant member of the gneissic complex, which is the oldest unit of this Precambrian terrain. Towards west of the study area, [20] described similar assemblage of Precambrian rocks as the Betul Group of rocks and tentatively suggested a magmatic arc type tectonic setting with intra-arc sedimentary belts. A brief summary of lithology, depositional conditions, climate and age of the Satpura Gondwana succession are given in Table 1.

\section{Methodology}

The present study mainly deals with petrography and Provenance of Pachmrhi Formation sandstones. The sampling of sandstone units was carried out at regular intervals of measured section keeping in view the physical variation between different units. Out of all collected 


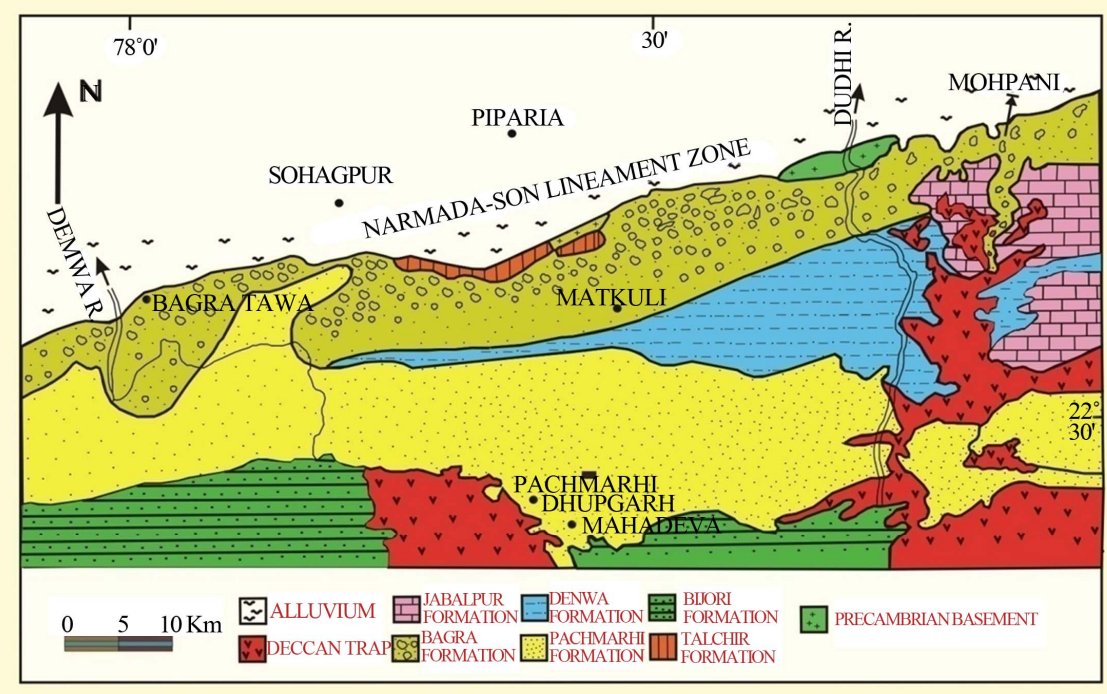

Figure 2. Geological map of Satpura Gondwana succession, central India (modified after Raja Rao, 1983).

sandstone samples twenty representative samples were cut into thin sections for petrographic study, which were etched and stained with sodium cobaltinitrite solution for identification of K-feldspar. Grain size measurements were carried out with the help of a micrometer eye piece. Chayes [21] point counting technique was employed and 300 - 350 grains were measured in each thin section. The size data was grouped into half-phi class interval. Cumulative frequency curves of grain size data were plotted on log probability paper. The grain diameters in phi units represented by $\Phi 5, \Phi 16, \Phi 25, \Phi 50, \Phi 75, \Phi 84$, and $\Phi 95$ percentiles were read from the size frequency curves. In the present study roundness scale given by Powers [22] with six roundness classes has been used. Mean roundness of each sample were determined by conventional statistical method employing the Powers class limit values. Roundness of the sand grains of each sample was measured by counting an average of about 300 grains per thin section. For pertofacies analysis, the detrital modes were recalculated to 100 percent by summing up of Qt, Qm, Qp, F, P, K, L, Lt, Lv and Ls framework constituents following Dickinson [23].

\section{Texture and Composition}

The present study is based on the twenty sandstone samples. Based on Folk [17] formulae, the various statistical parameters of grain size distribution like Graphic Mean $(\mathrm{Mz})$ and Inclusive Graphic Standard Deviation $(\sigma 1)$ are determined (Table 2). Graphic mean is a measure of central tendency, which is calculated by the formula $\Phi 16+$ $\Phi 50+\Phi 84 / 3$. The Mean grain size $(\mathrm{Mz})$ values of the studied samples ranges from $0.30 \Phi$ to $2.91 \Phi$ with an average of 1.87 . These samples are mainly medium grained followed by coarse grained and fine grained population. Variation in grain size is not uniform in several samples. Such variations suggest that during deposition the current was not of uniform strength. The inclusive graphic standard deviation $(\sigma 1)$ is the measure of sorting or uniformity of particle size distribution and it is calculated by the formula $(\Phi 84-\Phi 16) / 4+(\Phi 95$ $\Phi 5) / 6.6$. Inclusive graphic standard deviation $(\sigma 1)$ ranges from $0.59 \Phi$ to $1.22 \Phi$. Most of these sandstones are moderately sorted to moderately well sorted which indicates the fluctuating conditions of the current. It is well known that sorting of sediments depends upon competence and stability of currents, relatively constant strength currents produce very well sorted to well sorted sediments. These sandstones have grain roundness ranging from subangular to subrounded (2.0 $\Phi$ to $3.0 \Phi)$. For aggregate samples mean roundness value is $2.83 \Phi$. The framework constituents of the studied sandstone are mainly composed of quartz, feldspar, rock fragments and mica (Plate 1). The heavy minerals occur as minor constituents. These sandstones consist of various types of quartz including common detrital quartz, recrystallized and stretched metamorphic quartz. Feldspars are not much abundant in the studied sandstones. The feldspar grains belong to plagioclase, orthoclase and microcline. Both fresh and weathered varieties are common. The monocrystalline quartz generally shows undulatory extinction. Some of the quartz grains contain inclusion of rutile, zircon, tourmaline and micas. Polycrystalline quartz grains posses both sharp and sutured intercrystal boundaries. The rock fragments observed in this study include polycrystalline quartz grain (Qp), chert and lithic fragments including shale, phyllite and schist fragments. 


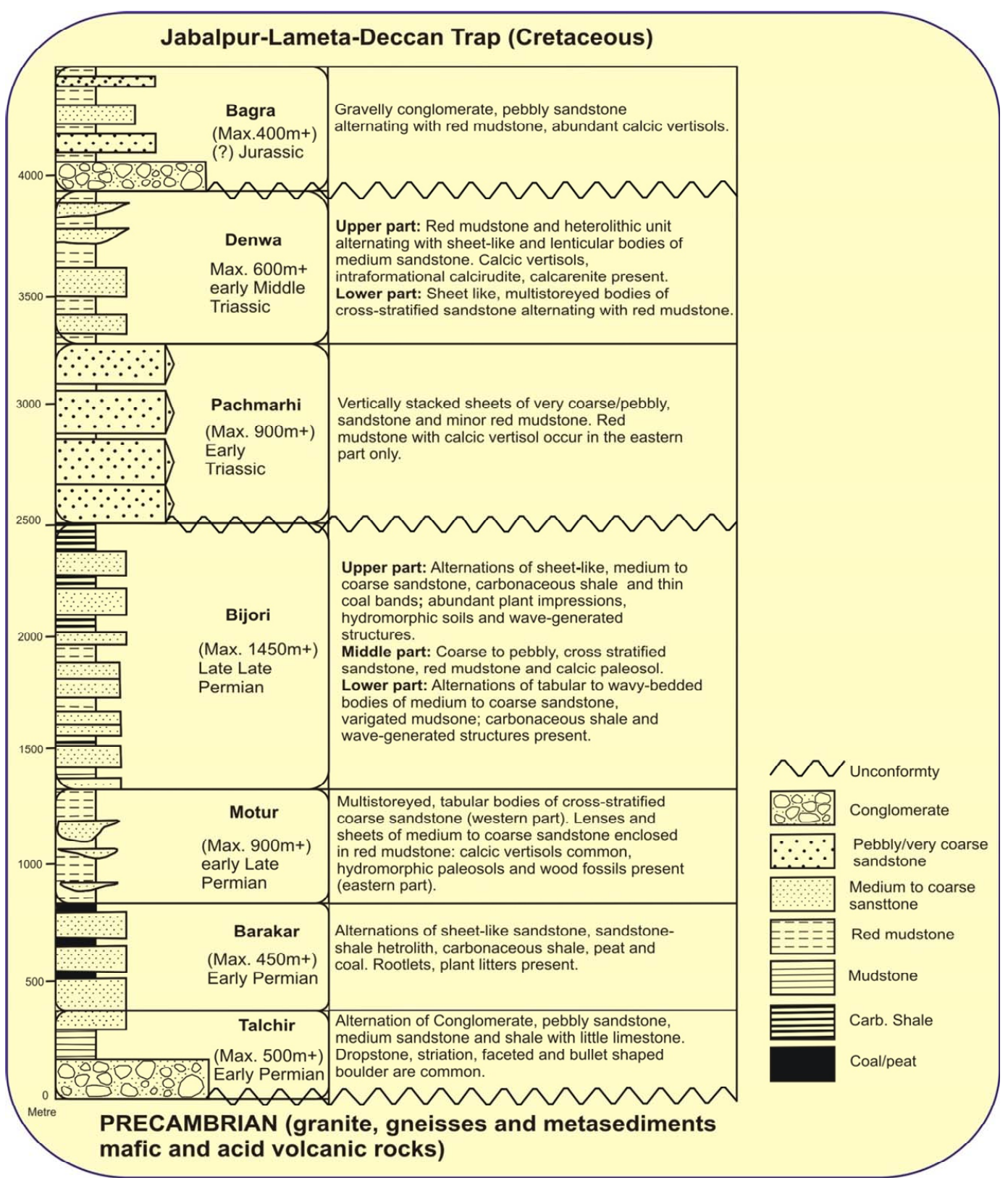

Figure 3. Generalized lithostratigraphy of the Gondwana succession in the eastern part of the Satpura basin (mainly after Ghosh et al., 2012).

According to Folk's [30] classification the Pachmarhi sandstones are quartzarenite and subarkose (Figure 4).

\section{Petrofacies and Tectono-Provenance}

Petrofacies, as defined by [31], implies detrital composition of sandstone and its significance to regional tectonic framework and contemporary tectonic activity in the source and depositional areas. The proportion of detrital framework grains plotted on triangular diagram provide effective discrimination of a variety of plate tectonic setting and have been used as powerful tool for determining the origin and tectonic reconstruction of terriginous de- posits [23]. In the present investigation, detrital minerals of Pachmari Sandstones were studied for the purpose of interpreting their provenance and tectonic setting using [23] classification scheme. In the present study the detrital modes were recalculated to 100 percent as the sum of Qt, Qm, Qp, P, K, L, Lt, Lv and Ls (Table 3). The intrabasinal and detrital limeclasts (Lc) do not occur and heavy minerals were excluded as they are highly variable as a result of hydrodynamic and geochemical influences. In this study four triangular diagrams, Qt-F-L, Qm-F-Lt, Qp-Lv-Ls and Qm-P-K were used (Table 3). Both Qt-F-L and Qm-F-Lt plots show full grain populations, 
Table 1. Stratigraphic succession of the Satpura Gondwana Basin (modified after Raja Rao, 1983 and Chakraborty and Ghosh, 2005).

\begin{tabular}{|c|c|c|c|c|c|}
\hline & Formations & Thickness & Lithology & $\begin{array}{l}\text { Depositional environment and } \\
\text { climate }\end{array}$ & Age \\
\hline \multirow[t]{4}{*}{$\begin{array}{c}\text { Upper } \\
\text { Gondwana }\end{array}$} & Bagra & Max. $400 \mathrm{~m}+$ & $\begin{array}{l}\text { Gravelly conglomerate, pebbly sandstone, } \\
\text { alternating with pedogenically modified red } \\
\text { mudstone, abundant calcic vertisols. Coarser } \\
\text { clastics define channel-like bodies, macroform bars } \\
\text { and are thoroughly cross-stratified. }\end{array}$ & $\begin{array}{l}\text { High gradient piedmont } \\
\text { rivers with braided morphology. } \\
\text { Alluvial tracts separated in space } \\
\text { by muddy plains. Subordinate } \\
\text { mass flow deposits [24]. Hot, } \\
\text { semi-arid to arid climate. }\end{array}$ & Jurassic (?) \\
\hline & & & 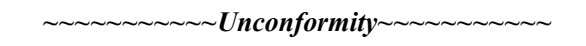 & & \\
\hline & Denwa & Max. $600 \mathrm{~m}+$ & $\begin{array}{l}\text { Upper part: Red mudstone and heterolithic unit } \\
\text { alternating with medium sandstone, sand-mud ratio } \\
\text { is 1:9, calcic vertisols and intraformational } \\
\text { calcirudite/calcarenite [13]. } \\
\text { Lower part: Sheet-like, multistoreyed, } \\
\text { cross-stratified sandstone bodies alternating with } \\
\text { red mudstone. Sand-mud ratio is 9:11 [15]. }\end{array}$ & $\begin{array}{l}\text { Lower part represents braided } \\
\text { channel deposits [15] and upper } \\
\text { part represents an anabranching } \\
\text { system. Warm, subhumid to } \\
\text { semi-arid climate [13,25]. }\end{array}$ & $\begin{array}{l}\text { Early Middle } \\
\text { Triassic (Early } \\
\text { Anisian) [27] }\end{array}$ \\
\hline & Pachmarhi & Max. $900 \mathrm{~m}+^{+}$ & $\begin{array}{l}\text { Pebbly sandstone. Sandstone bodies define thick } \\
\text { laterally extensive sheets that are superimposed } \\
\text { upon one another. Thoroughly cross-stratified. } \\
\text { Down-current dipping macroform stratification } \\
\text { common. Sandstone bodies separated by red } \\
\text { mudstones with calcic vertsols occur in the } \\
\text { eastern part only [15]. }\end{array}$ & $\begin{array}{l}\text { Braided river deposits }[15,26] \text {. } \\
\text { Predominantly warm, subhumid, } \\
\text { climate with semi-arid Intervals. }\end{array}$ & Early Triassic \\
\hline \multirow[t]{3}{*}{$\begin{array}{c}\text { Lower } \\
\text { Gondwana }\end{array}$} & Bijori & Max. $1450 \mathrm{~m}+^{+}$ & $\begin{array}{l}\text { Upper part: Alternations of sheet-like, medium } \\
\text { to coarse sandstone, carbonaceous shale and } \\
\text { thin coal bands; abundant plant impressions, } \\
\text { hydromorphic soils and wave-generated structures. } \\
\text { Middle part: Coarse to pebbly } \\
\text { cross-stratified sandstones, red mudstones } \\
\text { and calcic paleosols [12]. } \\
\text { Lower part: Alternations of tabular to wavy-bedded } \\
\text { bodies of medium to coarse } \\
\text { sandstone, variaegated mudstone; carbonaceous } \\
\text { shale and wave-generated structures present. }\end{array}$ & $\begin{array}{c}\text { Lower and upper part: Lake } \\
\text { shorelines, sub-aqueous } \\
\text { distributory channels and } \\
\text { associated levees, wave- and } \\
\text { storm-affected delta front and } \\
\text { open lacustrine/lower shore face } \\
\text { deposits. } \\
\text { Middle part: Fluvial channels and } \\
\text { associated flood plains. Warm, } \\
\text { semi-arid climate with seasonal } \\
\text { rainfall in the middle part; more } \\
\text { humid regimes during lower and } \\
\text { upper intervals [12]. }\end{array}$ & $\begin{array}{l}\text { Late Late Permian } \\
\text { (Early Tatarian) } \\
\text { [28] }\end{array}$ \\
\hline & Motur & Max. $900 \mathrm{~m}+$ & $\begin{array}{l}\text { Multistoreyed, cross-stratified, coarse sandstone } \\
\text { (mainly in the western part). Red } \\
\text { mudstone-dominated succession with embedded } \\
\text { lenses and sheets of medium to coarse sandstone; } \\
\text { sandstone:mudstone varies from 1:10 to 3:1; calcic } \\
\text { vertisols common in the red mudstones, } \\
\text { hydromorphic paleosols present at places; } \\
\text { silicified wood fossils present (mainly in the } \\
\text { eastern part) [16]. }\end{array}$ & $\begin{array}{l}\text { Braided, bedload channel } \\
\text { deposits. Anastomosed channel } \\
\text { deposits. Predominantly semi-arid } \\
\text { climate [16] possibly with } \\
\text { intermittent wet periods towards } \\
\text { later phase of the sedimentation. }\end{array}$ & $\begin{array}{l}\text { Early Late } \\
\text { Permian } \\
\text { (Ufimian-Kazanian) } \\
\text { [16] }\end{array}$ \\
\hline & Barakar & Max. $450 \mathrm{m+}$ & $\begin{array}{l}\text { Alternation of sandstone, sandstone-shale } \\
\text { heterolith and carbonaceous shale/peat/coal. } \\
\text { Two types of sandstone bodies: 1) coarse sandstone } \\
\text { characterized by unidirectional cross-sets, 2) } \\
\text { medium sandstone characterized by hummocky } \\
\text { crossstratification, tidal bundles. Sandstone-shale } \\
\text { heteroliths show flaser, lenticular and wavy } \\
\text { bedding. Rootlets, plant litters present. Three } \\
\text { major coal seams inter-bedded with sandstones in } \\
\text { the upper part of the formation. Contact with the } \\
\text { Talchir Formation is gradational [14]. }\end{array}$ & $\begin{array}{l}\text { Tidally influenced delta front } \\
\text { deposit, delta top interdistributory } \\
\text { deposits, delta top braided } \\
\text { channel deposits. } \\
\text { Temperate-humid climate [14]. }\end{array}$ & $\begin{array}{l}\text { Early Permian } \\
\text { (Kungurian) [29] }\end{array}$ \\
\hline
\end{tabular}




Alternation of conglomerate, pebbly sandston
medium sandstone and shale with little limesto
Two types of sandstone bodies: 1) coarse sandst
characterized by unidirectional cross-strata, 2
Medium sandstone characterized by hummocky, $\quad$ Max. $500 \mathrm{~m}+\quad$
swaley, low-angle cross-strata, parallel and wa
ripple lamination. Dropstone, striation, faceted
bullet-shaped boulders are common [1]].
$\sim \sim \sim \sim \sim \sim \sim \sim \sim$ Unconformity
Tonalite gneiss, granites, metasediments,
mafic and acid volcanic
rocks

Ice-contact fan delta, outwash braid-plain delta and a virtually ice-free, non-deltaic open marine condition (shoreface and offshore shelf); cold, arid climate [11].
Early Permian (Sakmarian) [29]

Table 2. Statistical parameters for grain size distribution of the pachmarhi sandstones of the Satpura Gondwana Basin, Madhya Pradesh.

\begin{tabular}{|c|c|c|c|c|}
\hline \multirow{2}{*}{ Sample No. } & \multicolumn{2}{|c|}{ Inclusive Graphic Mean (Mz) } & \multicolumn{2}{|c|}{ Inclusive Graphic Standard Deviation( $\sigma 1)$} \\
\hline & $\mathbf{M z}$ & Verbal Limit & $\sigma 1$ & Verbal Limit \\
\hline PM1 & 2.31 & Medium grained & 0.96 & Moderately sorted \\
\hline PM2 & 1.73 & Medium grained & 0.71 & Moderately well sorted \\
\hline PM3 & 0.91 & Coarse grained & 0.78 & Moderately sorted \\
\hline PM4 & 1.35 & Medium grained & 0.60 & Moderately well sorted \\
\hline PM5 & 1.81 & Medium grained & 0.71 & Moderately well sorted \\
\hline PM6 & 2.5 & Medium grained & 1.26 & Poorly sorted \\
\hline PM7 & 1.6 & Medium grained & 0.83 & Moderately sorted \\
\hline PM9 & 2.91 & Medium grained & 0.59 & Moderately well sorted \\
\hline PM10 & 2.3 & Medium grained & 0.73 & Moderately sorted \\
\hline PM11 & 1.15 & Medium grained & 0.87 & Moderately sorted \\
\hline PM12 & 0.30 & Coarse grained & 1.22 & Poorly sorted \\
\hline PM13 & 2.73 & Medium grained & 0.69 & Moderately well sorted \\
\hline PM14 & 2.36 & Medium grained & 0.90 & Moderately sorted \\
\hline PM15 & 1.35 & Medium grained & 0.90 & Moderately sorted \\
\hline PM16 & 1.36 & Medium grained & 1.04 & Poorly sorted \\
\hline PM17 & 1.38 & Medium grained & 0.97 & Moderately sorted \\
\hline PM19 & 2.3 & Medium grained & 0.91 & Moderately sorted \\
\hline PM20 & 2.73 & Medium grained & 0.69 & Moderately well sorted \\
\hline Average & 1.87 & & 0.88 & \\
\hline
\end{tabular}

but, with different emphasis. The Qt-F-L diagram emphasizing factors controlled by provenance, relief, weathering and transport mechanism as well as source rock, based on total quartzose, feldspathic and lithic modes. In this diagram, the studied sample data plot in the continental block provenance field and clustering 


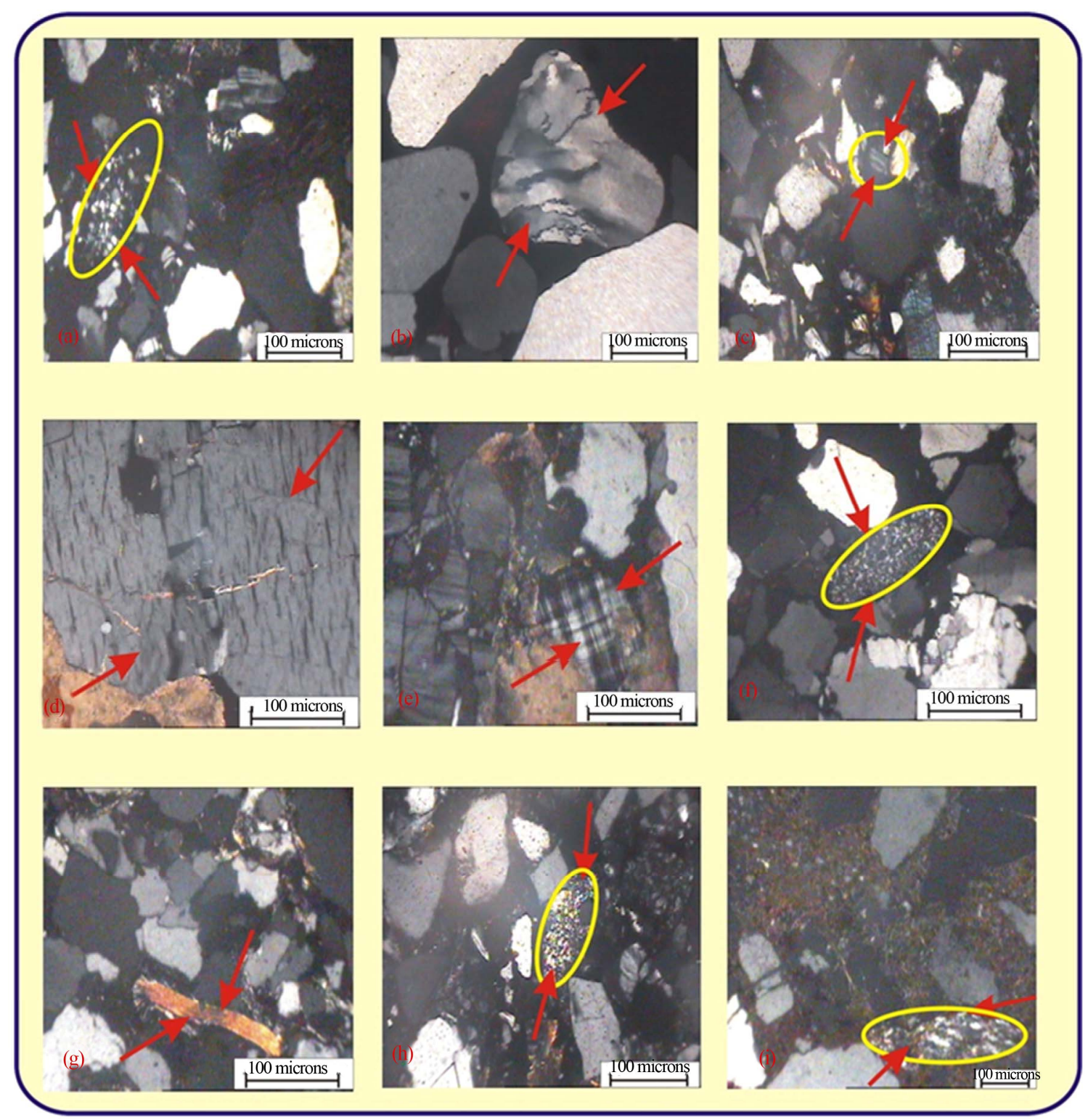

Plate 1. Photomicrographs showing (a) Recrystallized metamorphic quartz, (b) Stretched metamorphic quartz, (c) Plagioclase, (d) Orthoclase, (e) Microcline, (f) Chert, (g) Mica, (h) Phyllite and (i) Schist grains.

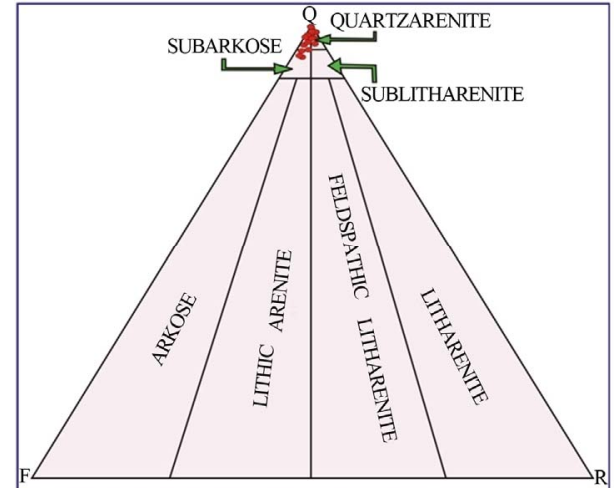

Figure 4. Classification of sandstones of the study area according to Folk's (1980) scheme. around Qt apex further suggests a stable continental cratonic source and more especially a craton interior orogen provenance (Figure 5(a)) [32]. Global sandstone petrographic classifications show that petrofacies that plot within the recycled orogen provenance field are commonly derived from metasedimentary and sedimentary rocks that were originally deposited along former passive continental margins [23,33]. In the Qm-F-Lt diagram, all unstable lithic fragments including the polycrystalline quartz are plotted together as Lt, to emphasize the source rocks. In this diagram, most of the sample data plots in the continental block to recycled orogen provenance suggesting a mixed input in the sedimentary basin (Figure 5(b)). The ratio of monocrystalline quartz to that of 
Table 3. Percentage of framework modes of the Pachmarhi Sandstones of the Satpura Gondwana basin, Madhya Pradesh. Based on Dickinson's classification (1985). Qt = Total quartz; Qm = Monocrystalline quartz; Qp = Polycrystalline quartz (including chert); $\mathbf{F}=$ Total feldspar grains; $P=$ Plagioclase grains; $K=$ K-Feldspar grains; $L=$ Total unstable lithic fragments; $\mathbf{L v}=$ Volcanic/metavolcanic lithicfragments; $\mathbf{L s}=$ Sedimentary/metasedimentary fragments; $\mathbf{L t :}(\mathbf{L}+\mathbf{Q p})$.

\begin{tabular}{|c|c|c|c|c|c|c|c|c|c|c|c|c|}
\hline Sample No. & $Q \mathbf{t}$ & $\mathbf{F}$ & $\mathbf{L}$ & Qm & $\mathbf{F}$ & $\mathbf{L t}$ & Qp & $\mathbf{L v}$ & Ls & Qm & $\mathbf{P}$ & K \\
\hline PM1 & 93 & 5 & 2 & 89 & 5 & 6 & 80 & - & 20 & 95 & 2 & 3 \\
\hline PM2 & 94 & 5 & 1 & 89 & 5 & 6 & 100 & - & 0 & 95 & 2 & 3 \\
\hline PM3 & 93 & 7 & - & 90 & 7 & 3 & 100 & - & 0 & 93 & 3 & 4 \\
\hline PM4 & 94 & 5 & 1 & 91 & 5 & 4 & 75 & - & 25 & 95 & 2 & 3 \\
\hline PM5 & 95 & 5 & - & 92 & 5 & 3 & 100 & - & - & 95 & 4 & 1 \\
\hline PM6 & 98 & - & 2 & 88 & - & 12 & 100 & - & - & 100 & - & - \\
\hline PM7 & 93 & 6 & 1 & 88 & 6 & 6 & 100 & - & - & 93 & 3 & 3 \\
\hline PM8 & 93 & 5 & 2 & 85 & 5 & 10 & 89 & - & 11 & 94 & 3 & 2 \\
\hline PM9 & 94 & 5 & 1 & 85 & 5 & 10 & 100 & - & - & 94 & 2 & 3 \\
\hline PM10 & 92 & 6 & 2 & 90 & 6 & 4 & 67 & - & 33 & 93 & 4 & 2 \\
\hline PM11 & 93 & 5 & 2 & 87 & 5 & 8 & 100 & - & - & 94 & 1 & 4 \\
\hline PM12 & 93 & 5 & 2 & 92 & 5 & 3 & 50 & - & 50 & 95 & 2 & 3 \\
\hline PM13 & 95 & 4 & 1 & 88 & 4 & 8 & 100 & - & - & 96 & 2 & 2 \\
\hline PM14 & 95 & 5 & - & 90 & 5 & 5 & 100 & - & - & 95 & 3 & 2 \\
\hline PM15 & 95 & 5 & - & 94 & 5 & 1 & 100 & - & - & 95 & 1 & 4 \\
\hline PM16 & 94 & 4 & 2 & 87 & 4 & 9 & 88 & - & 13 & 96 & 2 & 2 \\
\hline PM17 & 93 & 5 & 2 & 91 & 5 & 4 & 100 & - & - & 95 & 5 & - \\
\hline PM18 & 94 & 5 & 1 & 91 & 5 & 4 & 100 & - & - & 95 & 1 & 4 \\
\hline PM19 & 96 & 3 & 1 & 94 & 3 & 3 & 100 & - & - & 97 & 2 & 1 \\
\hline PM20 & 90 & 8 & 2 & 85 & 7 & 7 & 83 & - & 17 & 92 & 2 & 6 \\
\hline Average & 94 & 5 & 1 & 89 & 5 & 6 & 92 & - & 8 & 95 & 2 & 3 \\
\hline
\end{tabular}

polycrystalline quartz reflects the maturity of the sediments and sedimentary rocks because the amount of polycrystalline quartz tends to reduce by recycling and weathering [34]. The Qp-Lv-Ls plot, which is based on rock fragment population reveals the poly-minerallic component of source region and gives a more resolved picture about the tectonic elements. The sample data plot in rifted continental margin basin setting and few in thrust belt setting only (Figure 6(a)) reflecting no contribution from the volcanic source. The Qm-P-K plot of the data shows that all the sediment contribution is from the continental block basement uplift provenance (Figure 6(b)) and is reflected in mineralogical maturity of the sediments. As a whole petrofacies analysis indicates that the detrital components of Pachmari were derived mainly from continental block provenance, cratonic source, especially from a cratonic interior.

\section{Discussion}

Among the several factors influencing the detrital mineralogy of sandstones, the lithological composition of the rocks in the source area may be the most potent and dominating agent that affects the final sandstone composition [35]. The various types of source rocks produce different suite of detrital minerals which reveal the character of that rock from which the suites have originated. A study of both the light and heavy minerals of the sandstone is important in interpreting the provenance character. Among the light minerals, quartz is the dominant constituent of the sandstone. Therefore, study of detrital quartz can provide an insight to the ultimate source of rocks. Heavy minerals provide exceptionally useful clue to the nature of source rocks. Like lighter fractions, they too are influenced by weathering, transportation and diagenesis. The Sandstones of the study area contain 


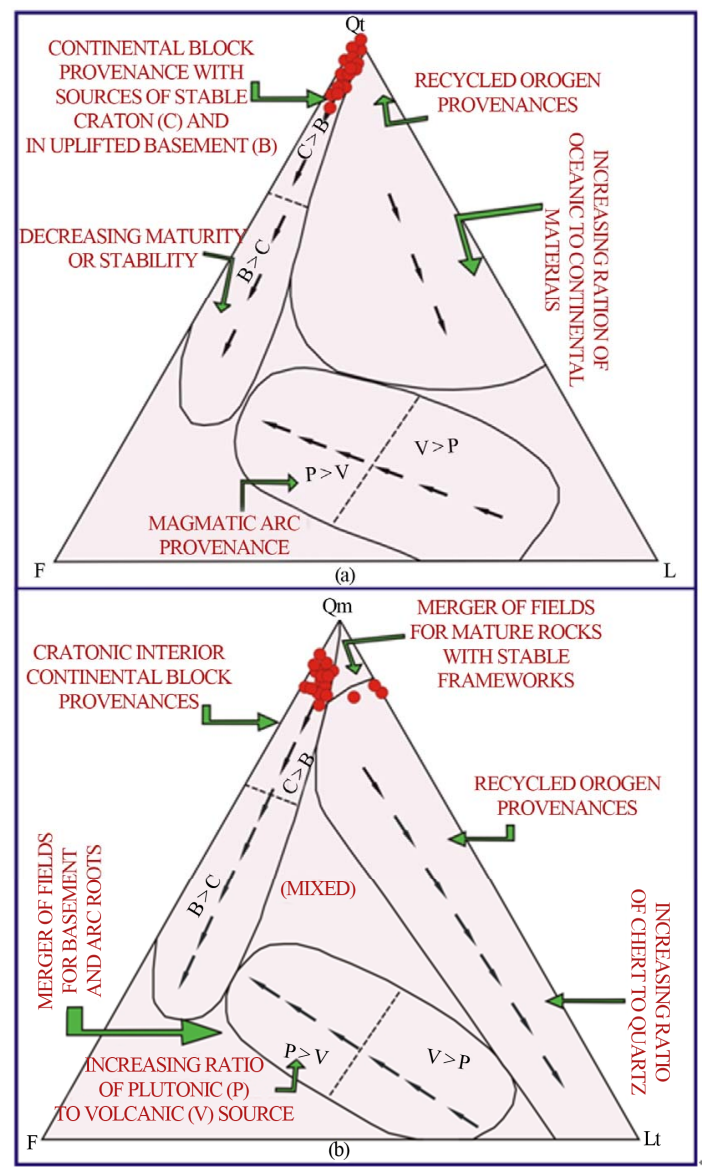

Figure 5. Classification of the Pachmarhi sandstone, (according to Dickinson, 1985), (a) Qt-F-L and (b) Qm-F-Lt.

quartz of igneous (common quartz) and metamorphic (recrystallised metamorphic quartz, stretched metamorphic quartz) origin as well as micas, rock fragments, heavy mineral and feldspar. Plutonic (common) quartz is the predominant mineral constituent in the study area. It is mainly derived from granitic batholiths or granitic gneisses. Vein quartz suggests derivation from pegmatites, hydrothermal and much more rarely sedimentary vein fillings. The recrystallised metamorphic quartz indicates an origin from metaquartzite, highly metamorphosed granite and gneissic rocks. The stretched metamorphic quartz was probably derived from granite, schist. Mica present in the studied sandstones comprises mainly muscovite and a few biotite grains derived probably from granite, pegmatite or schist. The suite of heavy minerals with biotite, tourmaline and zircon indicate acid igneous source for these sediments. On the other hand the suite of heavy minerals including garnet and epidote reflects metamorphic source. Rounded to sub rounded grains of tourmaline, rutile and zircon is indicative of multicycled source for the sediments. The petrofacies analysis of the Pachmarhi Sandstone indicates multiple rock sources for these sandstones which are not reflected in the triangular plots.

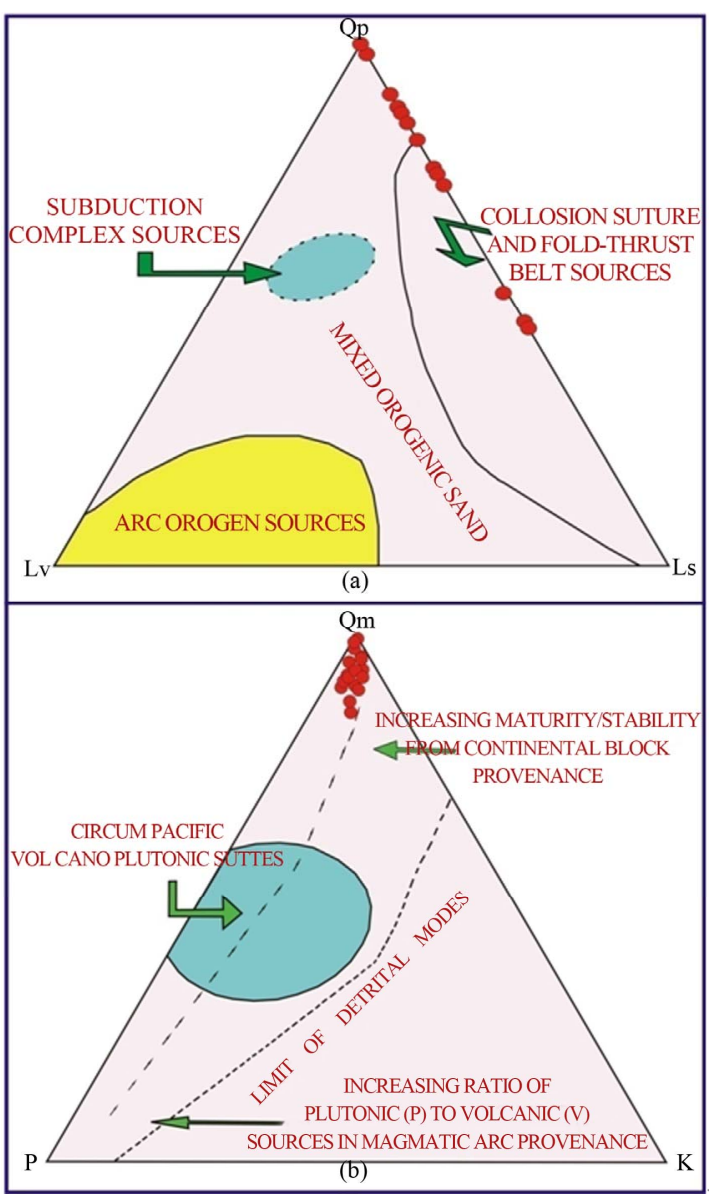

Figure 6. Classification of the Pachmarhi sandstone, (according to Dickinson, 1985), (a) Qp-Lv-Ls and (b) Qm-P-K.

The apparent reason for this could be diagenetic alteration and weathering of unstable framework grains and consequent increase in the proportion of quartz grains.

\section{Conclusion}

The Pachmarhi sandstone is medium to coarse grained, moderately to moderately well sorted, subangular to subrounded and of moderate sphericity and composed of several varieties of quartz, feldspar, rock fragments, mica and suite of heavy minerals. The provenance had mixed source comprising of the Precambrian granites, gneiss and metasedimentary rocks straddling the southern margin of the basin. The plots of the Pachmarhi Sandstone on Qt-F$\mathrm{L}$ and Qm-F-Lt diagrams suggest that the sediment supply from the continental block and more specially a craton interior. The Qm-P-K diagram suggest that the maturity of sediments and stability of the source area. The sediments were deposited in an intracratonic, rifted (pull-apart) basin conditions as evidenced from Qp-Lv-Ls diagrams.

\section{Acknowledgements}

The authors gratefully thank the Chairman, Dr. L. A. K. 
Rao, Associate Professor, Department of Geology, Aligarh Muslim University, Aligarh for providing all necessary research facilities during this work. The comments and suggestions of the anonymous reviewer helped in improving the quality of the paper.

\section{REFERENCES}

[1] D. K. Hobday, "Gondwana Coal Basins of Australia and South Africa: Tectonic Setting, Depositional Systems and Resources,” In: A. C. Scott, Ed., Coal and Coal-Bearing Strata: Recent Advances, Geological Society of London Special Publications, Vol. 32, 1987, pp. 219-233.

[2] S. K. Acharyya, "Tectonic Setting and Nature of the Gondwanic Indian Crust. Proceedings Volume, International Seminar, Precambrian Crust in Eastern and Central India," Geological Survey of India, Special Publications, Vol. 57, 2000, pp. 1-8.

[3] S. K. Biswas, "A Review on the Evolution of Rift Basins in India during Gondwana with Special Reference to Western Indian Basins and Their Hydrocarbon Prospects. A. Sahni and R. S. Loyal, Eds., Gondwana Assembly: New Issues and Perspectives," Proceedings of Indian National Science Academy, Vol. 65, 1999, pp. 261-283.

[4] G. C. Chatterjee and P. K. Ghosh, "Tectonic Framework of Peninsular Gondwanas of India," Records Geological Survey of India, Vol. 98, 1970, pp. 1-15.

[5] N. D. Mitra, “Tensile Resurgence along Fossil Sutures: A Hypothesis on the Evolution of Gondwana Basins of Peninsular India," Abstracts of Proceedings of 2nd Symposium on Petroliferous Basins of India, Dehradun, 1994, pp. 55-62.

[6] S. M. Naqvi, D. Rao and H. Narain, "The Protocontinental Growth of the Indian Shield and the Antiquity of Its Rift Valleys,” Precambrian Research, Vol. 1, 1974, pp. 345-398. doi:10.1016/0301-9268(74)90005-9

[7] C. Chakraborty, N. Mandal and S. Ghosh, "Kinematics of the Gondwana Basins of Peninsular India," Tectonophysics, Vol. 377, No. 3-4, 2003, pp. 299-324. doi:10.1016/j.tecto.2003.09.011

[8] C. Chakraborty and S. K. Ghosh, "Pull-Apart Origin of the Satpura Gondwana Basin, Central India,” Journal of Earth System Science, Vol. 114, No. 3, 2005, pp. 259-273. doi:10.1007/BF02702949

[9] H. B. Medlicott, "Note on Exploration for Coal in the Northern Region of the Satpura Basin,” Recycling Geology Survey of India, Vol. 5, 1872, pp. 109-128.

[10] H. Crookshank, "Geology of the Northern Slopes of the Satpura between the Morand and Sher Rivers," Memoirs of the Geological Survey of India, Vol. 66, No. 2, 1936, pp. 173-381.

[11] C. Chakraborty and S. K. Ghosh, "Pattern of Sedimentation during the Late Paleozoic, Gondwanaland Glaciation: An Example from the Talchir Formation, Satpura Gondwana Basin, Central India,” Journal of Earth System Science, Vol. 117, No. 4, 2008, pp. 499-519. doi:10.1007/s12040-008-0049-3

[12] T. Chakraborty and S. Sarkar, "Evidence of Lacustrine
Sedimentation in the Upper Permian Bijori Formation, Satpura Gondwana Basin: Palaeogeographical and Tectonic Implications,” Journal of Earth System Science, Vol. 114, No. 3, 2005, pp. 303-323. doi:10.1007/BF02702952

[13] P. Ghosh, S. Sarkar and P. Maulik, "Sedimentology of a Muddy Alluvial Deposit: Triassic Denwa Formation,” Sedimentary Geology, Vol. 191, No. 1-2, 2006, pp. 3-36. doi:10.1016/j.sedgeo.2006.01.002

[14] S. K. Ghosh, C. Chakraborty and T. Chakraborty, "Combined Tide and Wave Influence on Sedimentation of Lower Gondwana Coal Measures of Central India: Barakar Formation (Permian), Satpura Basin,” Journal of Geological Society of London, Vol. 161, No. 1, 2004, pp. 117-131. doi:10.1144/0016-764902-077

[15] P. K. Maulik, C. Chakraborty, P. Ghosh and D. Rudra, "Meso and Macro Scale Architecture of a Triassic Fluvial Succession: Denwa Formation, Satpura Gondwana Basin, M. P.," Journal of Geological Society of India, Vol. 56, No. 5, 2000, pp. 489-504.

[16] S. Ray and T. Chakraborty, "Lower Gondwana Fluvial Succession of the Pench-Kanhan Valley, India: Stratigraphic Architecture and Depositional Controls," Sedimentary Geology, Vol. 151, No. 3-4, 2002, pp. 243-271. doi:10.1016/S0037-0738(01)00260-3

[17] S. K. Ghosh, "First Record of Marine Bivalves from the Talchir Formation of the Satpura Gondwana Basin, India: Palaeobiogeographic Implications,” Gondwana Research, Vol. 6, No. 2, 2003, pp. 312-320. doi:10.1016/S1342-937X(05)70980-1

[18] C. R. Scotese, "Atlas of Earth History 1, Paleogeography, Paleomap Project, Arlington, Texas,” 2001.

[19] C. R. Scotese, "http://www.scotese.com (Paleomap Website)," 2002.

[20] A. Roy, S. A. Chore, L. L. Viswakarma and K. Chakraborty, "Geology and Petrochemistry of Padhar MaficUltramafic Complex from Betul Belt: A Study on ArcType Magmatism in Central Indian Tectonic Zone,” Geological Survey of India, Special Publications, Vol. 84, 2004, pp. 297-318.

[21] F. Chayes, "A Simple Point Counters for the Thin Section Analysis,” American Mineralogist, Vol. 34, 1949, pp. 1-11.

[22] M. C. Power, "A New Roundness Scale for Sedimentary Particles,” Journal of Sedimentary Petrolium, Vol. 23, 1953, pp. 117-119.

[23] W. R. Dickinson, "Interpreting Relations from Detrital Modes of Sandstone,” In: G. G. Zuffa, Ed., Provenance of Arenites, Reidel, Dordrecht-Boston-Lancaster, 1985, pp. 333-361.

[24] S. M. Casshyap, R. C. Tewari and A. Khan, “Alluvial Fan Origin for Bagra Formation (Mesozoic Gondwana) and Tectono-Stratigraphic Implications," Journal of Geological Society of India, Vol. 42, No. 3, 1993, pp. 262-279.

[25] P. Ghosh and S. Sarkar, "Pedogenic and Sedimentologic Criteria for Recognition of Overbank Sub-Environments in a Triassic Anabranching-River Deposit,” In: S. Davidson, C. P. North and S. Leleu, Eds., From River to Rock Record: The Preservation of Fluvial Sediments and Their 
Subsequent Interpretation, SEPM Special Publications, Vol. 97, 2011, pp. 125-142.

[26] R. C. Tewari, “Tectono-Sedimentary Evolution of Bijori (Late Permian) and Pachmarhi (Early Triassic) Formations of Satpura Gondwana Basin, Central India,” Indian Journal of Petrolium Geology, Vol. 4, 1955, pp. 75-86.

[27] S. Bandyopadhyay and D. P. Sengupta, "Middle Triassic Vertebrates of India," Journal of African Earth Science, Vol. 29, No. 1, 1999, pp. 233-241. doi:10.1016/S0899-5362(99)00093-7

[28] R. Werneburg and J. Schneider, "The Permian Temnospondyle Amphibians of India,” In: A. R. Milner, Ed., Studies on Carboniferous and Permian Vertebrates, Special Paper Palaeont, Vol. 52, 1996, pp. 105-128.

[29] P. L. Robinson, "The Indian Gondwana Formations: A Review," 1st IUGS International Symposium on Gondwana Stratigraphy UNESCO, Buenos Aires, 1967, pp. 201268.

[30] R. L. Folk, “Petrology of Sedimentary Rocks,” Hemphill, Austin, 1980.
[31] W. R. Dickinson and E. I. Rich, "Petrologic Intervals and Petrofacies in the Great Valley Sequence, Sacramento Valley, California," Geological Society of America Bulletin, Vol. 83, No. 10, 1972, pp. 3007-3024. doi:10.1130/0016-7606(1972)83[3007:PIAPIT]2.0.CO;2

[32] W. R. Dickinson, "Provenance and Sediment Dispersal in Relation to Paleotectonics and Paleogeography of Sedimentary Basins,” In: K. L. Kleinspehn and C. Poala, Eds., New Perspective in Basin Analysis, Springer, New York, 1988, pp. 3-25.

[33] W. R. Dickinson and C. A. Suczek, "Plate-Tectonics and Sandstones Composition," American Association of Petroleum Geologists Bulletin, Vol. 63, 1979, pp. 2164-2182.

[34] A. Basu, "Influence of Climate and Relief on Composition of Sand Release at Source Areas,” In: G. G. Zuffa, Ed., Provenance of Arenites, Reidel, Dordrecht-BostonLancaster, 1985, pp. 1-18.

[35] P. D. Krynine, "Microscopic Morphology of Quartz Types," Annuel 2nd Congress Panamas Ing Minas Geology, Vol. 3, 1946, pp. 35-49. 